\title{
TRAINING OF HUMAN RESOURCES AS AN ELEMENT OF DEVELOPMENT AND BUILDING DISCIPLINE
}

\author{
Marcin OLKIEWICZ \\ Koszalin University of Technology, Faculty of Economic Sciences; marcin.olkiewicz@tu.koszalin.pl, \\ ORCID: 0000-0001-6181-6829
}

\begin{abstract}
Purpose: The publication's purpose is to demonstrate how training affects the development of soldiers in the armed forces and shapes discipline within the military.

Design/methodology/approach: As part of the conducted works, the following research questions were raised: Q1. Is the amount of training sufficient to ensure proper development of a soldier and to make him follow instructions and orders? Q2. Do superiors use all available forms of training? A total of 103 soldiers of the Repair Battalion participated in the study from March to April 2018.

Findings: The study shows that the delivered trainings ensure the proper functioning of the unit, an appropriate level of discipline and provide a soldier with an opportunity to develop professionally. However, only $53.7 \%$ of soldiers believe that superiors use all available forms of training. This may be caused by inadequate knowledge of the legal acts, which was confirmed by up to $30 \%$ of the respondents.

Originality/value: This publication covers the subject of human resource management, in particular the area of training, emphasising: the importance of knowledge of the legal acts (specificity of the organisation under study) that affect the "training programme" and the number of trainings necessary to exercise the profession and to apply for promotion, as well as to shape the expected level of discipline. This paper is dedicated to people involved in the training and/or management of human resources and civil servants.
\end{abstract}

Keywords: trainings, human resource management, knowledge of the law, promotion.

Category of the paper: Research paper.

\section{Introduction}

Currently, there are many definitions on human resource management in literature (Vásquez-Torres, 2017; Moczydłowska, 2010), of which a few chosen examples are presented in Table 1. An analysis of the definitions allows one to distinguish certain constant elements defining human resource management as a comprehensive, strategic approach to managing people employed in an organisation and to achieve, through the proper deployment (Armstrong, 
2010) of qualified staff members within an organisation, the competitive advantage necessary for the effective functioning of a company on the market.

Table 1.

Selected definitions of human resource management

\begin{tabular}{|l|l|}
\hline J. Storey & $\begin{array}{l}\text { Human resource management is an approach to employment management which seeks to } \\
\text { achieve competitive advantage through the strategic deployment of a highly committed } \\
\text { and capable workforce using an array of cultural, structural and personnel techniques. }\end{array}$ \\
\hline M. Armstrong & $\begin{array}{l}\text { Human resource management is a strategic and coherent approach to the management of } \\
\text { the most valued asset of organisations - people working in them, who individually and } \\
\text { collectively contribute to the achievement of the employer's objectives. }\end{array}$ \\
\hline $\begin{array}{l}\text { A. Król, } \\
\text { A. Ludwiczyński }\end{array}$ & $\begin{array}{l}\text { Human resource management can be treated as a modern model of personal function in } \\
\text { organisations. The objective is to shape, adapt and use human resource management in a } \\
\text { way that allows an organisation to fully achieve its plans while taking into consideration } \\
\text { the interests of the owners and employees. Human resource management should include } \\
\text { comprehensive actions carried out in a harmonised way. }\end{array}$ \\
\hline B. Adamiec, Kożusznik & $\begin{array}{l}\text { Human resource management is nothing more than a strategy and practice of recruitment, } \\
\text { use and improvement of workers, as well as to retain skilled workers in the company. }\end{array}$ \\
\hline A. Pocztowski & $\begin{array}{l}\text { Human resource management is a specific management concept in the area of an } \\
\text { organisation's personnel function, in which human resources are perceived as the } \\
\text { company's asset and a source of competitiveness. In human resource management, } \\
\text { the strategic integration of personal matters with business matters and the active role of } \\
\text { line management in solving personnel issues is postulated. Also, it indicates the need to } \\
\text { shape organisation's culture, integration of the personnel processes and the improvement } \\
\text { of the employees' commitment as a tool for achieving objectives. }\end{array}$ \\
\hline
\end{tabular}

Adapted from: "Zarządzanie zasobami ludzkimi" by M. Armstrong, 2000; "Zarządzanie zasobami ludzkimi. Tworzenie kapitału ludzkiego organizacji” by H. Król and A. Ludwiczyński, 2006; "Zarządzanie zasobami ludzkimi” by M. Adamiec and B. Kożusznik, 2000; “Zarządzaniezasobamiludzkimi” by A. Pocztowski, 2003.

As part of process activity (cyclical) (Reigeluth, 2012; Wood and Dickinson, 2011), training is often used in the area of human resource management, specifically reflected in the organisation of work, the process of acquiring and developing the workforce, remuneration, etc. (Ściborek, 2010; Listwan, 2006; Nichols, 2016).

An organisation's concern for the worker is reflected in staff development and is an element of investing in human resources (Vásquez-Torres, 2017; Clark and Waldron, 2016; Doxford and Judd, 2002). It is, therefore, a result of recognition of his needs and individual capabilities and should be implemented based on the designed development plan for employees. The staff development concept has to be done in close connection with the staff appraisal and training systems. The objective of employee training is to provide him with the necessary skill set to perform the job to which he was hired to do or to improve his qualifications in terms of the already occupied or future work place (Baron and Agustina, 2017; Gajdzik, 2018; Rick et al., 2017). Training is an essential part through which an organisation maintains or increases the effectiveness of its workforce (Burley et al., 2018; Kyröläinen et al., 2018; Larsen et al., 2018; Griffin, 2017). Therefore, trainings are divided into: 
- introduction and preparation for work (includes equipping new employees with the knowledge and skills necessary to perform duties in the new work place),

- improvement (expanding or updating knowledge in the event of changes to the provisions governing it),

- retraining (obtaining new knowledge and skills to perform a new or planned job, inside or outside the organisation).

The evaluation of the effectiveness of training should be made based on the assessment of the following elements (Koźminski and Piotrowski, 2000):

- response - assessment of the usefulness of training, trainers and materials presented by the trainees. This can be achieved through interviews or surveys,

- learning - based on changes in the efficiency of work, it can be assessed to what extent the worker has acquired new knowledge,

- behaviours - can be checked by testing new knowledge and skills at a specific time through, for example, tests or test assignments,

- organisation - evaluation of whether the training is compliant with the organisation's strategy and if it contributes to its development.

The provision, frequency, scope of training and assessment depend on the specifics of the organisation and those supervising. The Armed Forces of the Republic of Poland is a hierarchically structured institution with a culture of unconditional submission to instructions and orders, subjected to the process of formalisation with its basics specified in the following documents:

- the Act of 11 September 2003 on the military service of professional soldiers,

- the Act of 9 October 2009 on military discipline,

- the Regulation of the Minister of National Defence of 23 June 2010 on rewarding soldiers, former soldiers and sub-units, units and military institutions.

The Act of 11 September 2003 on the military service of professional soldiers sets forth the rules for the appointment of a candidate for military service and the entities entitled to do so. It also regulates the course of military service across a range of different aspects, e.g. the rights and obligations of soldiers, emoluments and other liabilities of soldiers, as well as restrictions on public activity resulting from military service, professional development, etc.

To become a candidate for soldier or to receive a promotion, one has to meet the conditions specified in the Act of 11 September 2003 on the military service of professional soldiers (Journal of Laws 2003, No. 179, item 1750). Additionally, every candidate that wants to apply for admission to military service or as a part of development (for soldiers, different forms are provided) has to complete the following: 
1. For a candidate applying for the officer corps:

- a six-moth training course at a military university (for professional soldiers serving in NCOs and the private corps),

- one year of officers' studies at a military university (for candidates not being a part of the armed forces),

- a five-year military study at a military university (for high school graduates who have successfully passed their graduation exam).

2. For candidates applying for a position in the private corps:

- as part of preparatory service,

- training as a part of a rotational exercise (at least one).

The specificity of the organisation enforces the procedures of conduct in accordance with the specific provisions, which serve as a basic tool for shaping the development, discipline and skills of the unit and the individual groups of soldiers.

\section{Methods}

The objective of this paper is to assess the impact of training on the development of soldiers in the armed forces and the process of shaping military discipline. Therefore, the following research questions were raised:

Q1. Is the amount of training sufficient to ensure proper development of a soldier and to make him follow instructions and orders?

Q2. Do superiors use all available forms of training?

The research was carried out among soldiers from the Repair Battalion in the Pomeranian Province between March and April of 2018, and the documents on the disciplinary activity of the unit, which was the subject of an analysis, covered the years 2015-2017.

An analysis of the documents and an opinion poll in the form of a questionnaire were used in the conducted study. A total of 103 soldiers of the Repair Battalion (logistics unit) from different corps participated in the study (Table 2).

Table 2.

Participation of the surveyed soldiers in individual corps

\begin{tabular}{|l|c|c|c|}
\hline \multicolumn{1}{|c|}{ Corps } & Number of registered & Number of respondents & \% share \\
\hline Officer corps & 8 & 6 & $75 \%$ \\
\hline Non-commissioned officer corps & 68 & 38 & $56 \%$ \\
\hline Private corps & 70 & 59 & $84 \%$ \\
\hline Total & $\mathbf{1 4 6}$ & $\mathbf{1 0 3}$ & $\mathbf{7 1 \%}$ \\
\hline
\end{tabular}

Source: own study. 
The meeting was attended by $10.7 \%$ women and $89.3 \%$ men. The majority were young people $(46.7 \%)$, who were under 35 years of age in terms of the age structure. Only $13.6 \%$ of the respondents were over the age of 45 .

The data from Table 2 shows that the corps that are most numerous are the private corps with $5.8 \%$. The non-commissioned officer corps placed second, and the officer corps were last with $5.8 \%$ in the entire Battalion, amounting to 100 soldiers.

An analysis of the military service (experience) shows that the unit is comprised of soldiers with limited skills. As much as $45.6 \%$ of them took up military service within a period less than 10 years, and only $15.6 \%$ are soldiers with more than 20 years of military service.

\section{Results and discussion}

Due to the nature of the analysed Battalion, the development of soldiers takes place through a series of trainings. These are conducted based on the "Programme for logistics sub-division training", implemented by order no. 536 of the General Commander of the Armed Forces dated 25 October 2017. This programme sets forth the methods of planning and organising the training process, as well as its structure and the expected results of training, which will be subjected to subsequent verification, allowing for an assessment of a soldier's (sub-division's) level of training.

The structure of the military unit training process results from the training programme and includes a 36-months training cycle divided into stages and periods (Table 3).

\section{Table 3.}

Simplified structure of the training process

\begin{tabular}{|c|c|c|}
\hline & Garrison training & $\begin{array}{l}\text { Training as a part of the Polish Military } \\
\text { Contingents (PKW) }\end{array}$ \\
\hline $\begin{array}{l}1 \\
000 \\
80\end{array}$ & \multicolumn{2}{|c|}{$\begin{array}{l}\text { 1st period - personal improvement, team training and training aimed at reaching coordination at the } \\
\text { platoon level. }\end{array}$} \\
\hline $\begin{array}{l}\tilde{\omega} \\
\tilde{\omega}\end{array}$ & $\begin{array}{l}\text { 2nd period - coordination training as a sub-unit } \\
\text { (company, battalion). }\end{array}$ & $\begin{array}{l}\text { 2nd period - preparation to perform tasks beyond } \\
\text { national borders. }\end{array}$ \\
\hline 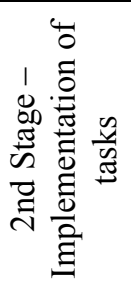 & $\begin{array}{l}\text { Training aimed at maintaining the ability and } \\
\text { readiness to act. }\end{array}$ & Performance of tasks beyond national borders. \\
\hline
\end{tabular}

Adapted from: Programu szkolenia pododdziałów logistycznych, Dowództwo Generalne Rodzajów Sił Zbrojnych, Bydgoszcz 2017, p. 6-14. 
The first stage "Training" lasts for 24 months and is divided into 2 periods:

- personal improvement, team training and training aimed at reaching coordination at the platoon level (12 months),

- coordination training as a sub-unit/preparation to perform tasks beyond national borders (12 months).

Delivery of the second training period has two options depending on whether the sub-division is planned to carry out tasks as a part of the Polish Military Contingents (PKW). In the case of intended use of the unit abroad, the training covers 4 phases:

1. planning,

2. preparation and formation,

3. training,

4. preparation for a rotation.

For the sub-unit carrying out tasks in a garrison, training aimed at coordinating the company and battalion is carried out.

The second stage of training "Implementation of tasks" envisages the performance of tasks under the Polish Military Contingent or maintaining the ability and readiness to act.

The planned trainings are carried out by the staff of a battalion with the help of the commanders of the sub-units (companies), based on the training programme and guidelines given by the superiors. The programme strictly imposes an hourly schedule, within which the basic goals set for each of the training subjects should be achieved (Table 4). In the framework of the planned training at the battalion level, the following documents are developed:

- a concept of tasks preparation and realisation - developed for a period of 3 years (updated annually),

- training programme prepared for years - developed for a period of 3 years (updated annually),

- a decision for a planned training year - based on the received task - with an attachment - a training diagram,

- a plan for specific undertakings for a period of 1 month,

- allocation plan for the training facilities.

Table 4.

Summary of programme hours in a 36-month training cycle

\begin{tabular}{|l|l|c|c|c|c|}
\hline \multirow{2}{*}{$\begin{array}{l}\text { The training } \\
\text { department }\end{array}$} & Subject & \multicolumn{2}{|l|}{ No. of hours } \\
\cline { 2 - 6 } & & Total & $\begin{array}{c}\text { 1st } \\
\text { year }\end{array}$ & $\begin{array}{c}\text { 2nd } \\
\text { year }\end{array}$ & $\begin{array}{c}\text { 3rd } \\
\text { year }\end{array}$ \\
\hline \multirow{2}{*}{$\begin{array}{l}\text { Civil and military } \\
\text { responsibility }\end{array}$} & $\begin{array}{l}\text { Regulations of the Armed Forces of the Republic of } \\
\text { Poland }\end{array}$ & $\mathbf{4 8}$ & 24 & 16 & 8 \\
\cline { 2 - 6 } & Civil education & $\mathbf{6 6 *}$ & 22 & 22 & 22 \\
\cline { 2 - 7 } & Prevention and military discipline & $\mathbf{9 9 *}$ & 33 & 33 & 33 \\
\hline
\end{tabular}


Cont. table 4.

\begin{tabular}{|c|c|c|c|c|c|}
\hline \multirow{14}{*}{ Military training } & Military mobilisation and combat readiness & 60* & 20 & 20 & 20 \\
\hline & Tactical and logistics training & 282 & 154 & 128 & \\
\hline & Target shooting training ${ }^{1)}$ (marksmanship) & 66* & 33 & 33 & \\
\hline & Emergency response & 32 & 16 & 16 & \\
\hline & $\begin{array}{l}\text { Enemy recognition and armies of other countries. } \\
\text { Electronic warfare }\end{array}$ & 28 & 16 & 12 & \\
\hline & Engineering and sapper's training & 41 & 21 & 20 & \\
\hline & Defence against weapons of mass destruction & 41 & 21 & 20 & \\
\hline & General anti-aircraft defence & 14 & 8 & 6 & \\
\hline & Communication & 16 & 12 & 4 & \\
\hline & Topography & 30 & 16 & 14 & \\
\hline & Site protection and defence & 27 & 16 & 11 & \\
\hline & Physical education & $528^{*}$ & 176 & 176 & 176 \\
\hline & Medical training & 64 & 32 & 32 & \\
\hline & Air assault training ${ }^{* * *}$ & 72 & 24 & 24 & 24 \\
\hline \multirow{6}{*}{ Logistics training } & Refresher training for a specific position & 1009* & 484 & 525 & \\
\hline & Construction and operation of the $\mathrm{SpW}$ & 88 & 44 & 44 & \\
\hline & Environmental Protection. & 4 & 2 & 2 & \\
\hline & Fire protection & 6 & 3 & 3 & \\
\hline & Safety and hygiene at work ${ }^{2)}$ & 8 & 8 & & \\
\hline & Driving lessons $^{3)}$ & 15 & 3 & 12 & \\
\hline \multirow{4}{*}{ General training } & Economic training & 10 & 4 & 6 & \\
\hline & Legal training ${ }^{4}$ & 23* & 12 & 8 & 3 \\
\hline & System to exploit experience ${ }^{5}$ & 1* & 1 & - & - \\
\hline & SERE (survival, evasion, resistance, escape) A, B, C6) & & 9 & 73 & \\
\hline \multicolumn{2}{|c|}{ Assessment of the degree of training } & 80* & 20 & 30 & 30 \\
\hline \multicolumn{2}{|c|}{ SpW Technical support ${ }^{7)}$} & 693 & 231 & 231 & 231 \\
\hline \multicolumn{2}{|c|}{ No. of hours at the commander's disposal } & 798 & 266 & 266 & 266 \\
\hline \multicolumn{2}{|c|}{$\begin{array}{l}\text { Combat, logistics and general training are to be performed during the } 2^{\text {nd }} \\
\text { stage of training and the following training cycles (subjects, topics, number } \\
\text { of hours are determined by the commander) }\end{array}$} & 891 & & & 891 \\
\hline \multicolumn{2}{|c|}{ No. of hours in total** } & 5070 & 1690 & 1690 & 1690 \\
\hline
\end{tabular}

*Minimal, mandatory number of hours.

**The maximum number of hours in a 36-month training cycle (hours and dates of the training at the disposal of the commander).

***To be realised only by the logistics sub-units of the air assault forces and the air cavalry. To be realised within the framework of the training cycle as determined by the commander.

Adapted from: Programu szkolenia pododdziałów logistycznych, Dowództwo Generalne Rodzajów Sił Zbrojnych, Bydgoszcz 2017, p. 28-29.

The garrison programme training includes 5 training days a week of 7 hours per day (45 minutes each). One day is left at the disposal of the commander of the sub-unit, where he can conduct training in conformity with his own decisions. In addition, the programme training is supplemented with courses aimed at maintaining skills by soldiers for practical action under specific conditions, e.g. general anti-aircraft defence training, where the proper behaviour of soldiers is shaped in the event of an air assault. 
The programme also requires exercises at military training grounds during the different stages of training with the following number of drill days:

- up to 12 days during the individual and team development training and coordination to the platoon level,

- up to 18 days (1-2 times a year) during the streamlining training period of the sub-unit (company, battalion),

- up to 18 days during the second stage of training (in the case of a non-performance of tasks of the whole sub-unit within the Polish Military Contingent (PKW)).

As part of exercises at the military training grounds, in order to make the best use of the provided training facilities and the planned limits of military resources, battlefield simulation and necessary products, the training programme is extended to 6 training days a week of 10 hours a day each.

The assessment of the level of training is carried out as an ongoing process by conducting tests that allow one to check the degree of training of individual soldiers in terms of knowledge acquisition and the skills specified in the training programme for a given subject. The sub-unit's operating readiness is checked by:

- usefulness and competition between combat teams- at the end of team coordination,

- tactical and logistics classes - at the end of platoon coordination,

- tactical and logistics exercises with the company - at the end of company coordination,

- tactical and logistics exercises with a battalion - at the end of the first stage of training and during the second stage at least once every 3 years in the subsequent training cycles.

An obligatory element in the assessment of the soldiers' training level is checking their target shooting skills by organising testing on a shooting range and the implementation of the training standards specified for the given training stage of a sub-unit.

The assessment of the degree of training is performed by the direct superior of the training unit, e.g. the usefulness and competition between combat teams at the end of the team coordination stage is made by the platoon commander. The supervisor of the subordinate sub-units should draw up the following:

- a plan for conducting the assessment of the sub-unit's degree of training,

- an evaluation report,

- a report to the superior about the sub-unit's readiness to perform combat-oriented tasks.

The report on the sub-unit's readiness to perform tasks as intended should contain information on the issues being the subject of the assignment, the identified shortcomings and suggestions on how to cope with them, as well as an assessment of the skills necessary to perform the given task by determining whether the sub-unit has "completed a task" or "failed to complete a task". Confirmation of the readiness to carry out the tasks by the subordinate sub-units serves as a basis for commencing the coordination training of the higher-level sub-unit. If the sub-unit has failed to complete the task, additional supplementary trainings for 
the soldiers/sub-units that achieved poorer performance should be planned in accordance with a separate plan approved by the immediate superior, allowing soldiers to reach the level of training necessary to move on to the next stage of training. Supplementary training is not included in the activities organised as part of the programme training.

With respect to the principle of the armed forces "Command-Train-Take responsibility", the commander of the sub-unit takes full responsibility for the implementation of the training programme and the results of the training achieved by the subordinate soldiers, which includes:

- direct preparation of subordinate commanders to take command during military operations,

- combat training of the commanded sub-unit for the completion of tasks as intended,

- training and coordination of the subordinate command (staff),

- coordination of the combat systems,

- direct preparation of the subordinate command to manage and implement training (including training and methodical activities by conducting an appropriate form of training and methodical activities),

- assessment of the level of training of the subordinate sub-units and post holders,

- instrumentation (as required) of the training process.

Furthermore, commanders of the sub-units should regularly improve their own methodological and substantive competences in planning and conducting training and raise their abilities to adapt the forms and methods used as a part of the training programme for the subordinate soldiers to perform tasks in actual military operations in the future.

Research showed that as much as $78.7 \%$ of the surveyed people believe that the number of trainings ensures an appropriate level of discipline, proper functioning and development that leads to promotion; $18.4 \%$ stated that trainings "rather provide" promotion, and only $2.9 \%$ declared that they "do not provide" promotion.

It is, however, necessary to emphasise that programme training is the primary task of the battalion, consisting in maintaining the habits, discipline and skills of each individual soldier and the sub-unit's coordination in the field of combat, as well as specialist training in the 3-year cycle under the "Training of the logistics sub-units" programme.

This is reflected in the statistics, where $57.3 \%$ of soldiers state that superiors use all available forms of training, 36.9\% have no opinion, and 5.8\% firmly believe that not all forms of training are used. Such a large diversity in opinions gives a feeling that soldiers have higher expectations and requirements, whereas superiors fail to meet these. This leads to an uncomfortable situation for the commanders, as the army should follow the principle of absolute discipline. To obtain the status quo, a high degree of formalisation is necessary, and the areas of operation have to be strictly defined by regulations, guidelines and, in particular, normative documents. However, studies show that knowledge of: 
- the Act of 11 September 2003 on the military service of professional soldiers was declared by $72.5 \%$ of the respondents (22.5\% “yes", $50.0 \%$ "rather yes"),

- the Act of 9 October 2009 on military discipline was declared by $75.8 \%$ of the respondents (24.3\% “yes", 51.5\% "rather yes"),

- the ordinance of the Minister of National Defence of 23 June 2010 on awarding soldiers, former soldiers and sub-units, units and military institutions was declared by $71.6 \%$ of the respondents (25.5\% “yes", $46.1 \%$ "rather yes").

On the basis of data, it can be stated that $30 \%$ of the respondents have little knowledge concerning basic legal acts. This may mean that superiors do not fully use the instruments intended to shape the discipline, and perhaps the development, of soldiers.

\section{Summary}

The presented results of the studies prove that uniformed services, including logistics units, require a continuous process of professional development. This applies both to legal knowledge (basic legal acts), organisational knowledge (operational procedures, intervention patterns, reporting, etc.), motivational knowledge, etc. The specialist trainings implemented as a part of a training cycle based on the "Training of the logistics sub-units" programme must be of the highest quality, with its efficiency constantly increasing. This will allow one to achieve and maintain the required level of discipline and satisfaction with professional development among soldiers. It can be assumed that there is a relationship between the professional development of soldiers and the level of discipline. The main limitation of the presented research is the fact that only one battalion was surveyed. In the future, it is worth expanding the scope of research to other units apart from logistics.

\section{References}

1. Adamiec, M., and Kożusznik, B. (2000). Zarządzanie zasobami ludzkimi. Kraków: Wydawnictwo AKA-DE.

2. Armstrong, M. (2000). Zarządzanie zasobami ludzkimi. Kraków: Oficyna Ekonomiczna.

3. Armstrong, M. (2010). Strategiczne zarzadzanie zasobami ludzkimi. Warszawa: Wolters Kluwer.

4. Baron, I.S., and Agustina, H. (2017). The effectiveness of leadership management training. Polish Journal of Management Studies, Vol. 16, No. 2, pp. 7-16. doi: 10.17512/ pjms.2017.16.2.0. 
5. Burley, S.D., Drain, J.R., Sampson, J.A., and Groeller, H. (2018). Positive, limited and negative responders: The variability in physical fitness adaptation to basic military training. Journal of Science and Medicine in Sport, Vol. 21, Issue 11, pp. 1168-1172. doi.org/10.1016/j.jsams.2018.06.018.

6. Clark, K.D., and Waldron, T. (2016). Predictors of Leadership Behavior in Early Career White Collar Professionals: The Roles of Personal Characteristics and Career Context. Journal of Leadership and Organizational Studies, Vol. 23, No. 1, pp. 27-38. doi/abs/10.1177/1548051815587759.

7. Doxford, D., and Judd, A. (2002). Army training: the environmental gains resulting from the adoption of alternatives to traditional training methods. J. Environ. Plann. Manag., 45(2), pp. 245-265. doi: 10.1080/09640560220116323.

8. Gajdzik, B. (2018). Model 70-20-10 uczenia się i rozwoju - argumenty za i przeciw. HRM, 1(120), pp. 167-181.

9. Griffin, R.W. (2017). Podstawy zarzadzania organizacjami. Warszawa: PWN.

10. Koźmiński, A.K., and Piotrowski, W. (2000). Zarządzanie potencjałem społecznym w organizacji. Teoria i praktyka. Warszawa: PWN.

11. Król, H., Ludwiczyński, A. (2006). Zarządzanie zasobami ludzkimi. Tworzenie kapitału ludzkiego organizacji. Warszawa: PWN.

12. Kyröläinen, H., Pihlainen, K., Vaara, J.P., Ojanen, T., Santtila, M. (2017). Optimising training adaptations and performance in military environment. Journal of Science and Medicine in Sport, Volume 21, Issue 11, pp. 1131-1138. doi.org/10.1016/ j.jsams.2017.11.019.

13. Larsen, T., Beier-Holgersen, R., Meelby, J., Dieckmann, P., Østergaard, D. (2018). A search for training of practising leadership in emergency medicine: A systematic review. Heliyon, Volume 4, Issue 11, pp. 1-23. doi.org/10.1016/j.heliyon.2018.e00968.

14. Listwan, T. (2006). Modele i składniki strategicznego zarządzania kadrami. In: W.T. Listwan (Eds.), Zarzadzanie kadrami. Warszawa: C.H. Beck.

15. Moczydłowska, J. (2010). Zarządzanie zasobami ludzkimi w organizacji. Podręcznik akademicki. Warszawa: Difin.

16. Nichols, A. (2016). What do people desire in their leaders? The effect of leadership experience on desired leadership traits. Leadership \& Organization Development Journal, Vol. 37, No. 5, pp. 658-671. doi.org/10.1108/LODJ-09-2014-0182.

17. Pocztowski, A. (2003). Zarzadzanie zasobami ludzkimi. Warszawa: PWE.

18. Program szkolenia pododdziałów logistycznych (2017). Bydgoszcz: Dowództwo Generalne Rodzajów Sił Zbrojnych.

19. Reigeluth, C.M. (ed.) (2012). Instructional Design Theories and Models. Hillsdale: Erlbaum.

20. The Act of September 11, 2003 on the military service of professional soldiers.

21. The Act of October 9, 2009 on the military discipline. 
22. The Regulation of the Minister of National Defence of June 23, 2010 on rewarding soldiers, former soldiers and sub-units, units and military institutions.

23. Vásquez-Torres, M.C. (2017). Variations in the perception of the elements that constitute training based on company size, employee seniority, and company age. Management, Vol. 21, No.1, pp. 148-178. doi: 10.1515/manment-2015-0086.

24. Wood, J., and Dickinson, J. (2011). Quality Assurance and Evaluation in the Lifelong Learning Sector. Exeter: Learning Matters.

25. Zentelis, R., Banks, S., Roberts, J.D., Dovers, S., Lindenmayer, D. (2017). Managing military training-related environmental disturbance. Journal of Environmental Management, 204, pp. 486-493. doi.org/10.1016/j.jenvman.2017.09.029. 